\title{
Use of the delayed luminescence test for evaluation of changes in frost-resistance of winter wheat
}

\section{ALEKSANDER BRZOSTOWICZ, ZDZISLAW PROKOWSKI, ANTONI MURKOWSKI, EDWARD GRABIKOWSKI}

\author{
Department of Physics, Agricultural University, ul. Janosika 8, \\ 71-424 Szczecin, Poland
}

$\langle$ Received: May 16, 1983〉

\begin{abstract}
The influence of frost hardening conditions on the frost-resistance of three winter wheat cultivars 〈'Mironowska 808', 'Grana' and 'Maris Huntsman'〉 was studied. Frost resistance was measured periodically during the autumn and winter season by the delayed luminescence method. Parallelly an electrical conductivity test was performed for comparison. It was found that the temperature which delayed luminescence reaches its maximum $\left\langle t_{N}\right\rangle$ correlates with $\left\langle\mathrm{t}_{50}\right\rangle$ obtained by the conductometric method.

The differences in response of particular cultivars to frost and hardening conditions are described.
\end{abstract}

\section{INTRODUCTION}

One of the main indices of hardiness of plants is their frost-resistance, a hereditary trait, which comes into play during the autumn-winter period of becoming accustomed to cold. The development of this trait is a dynamic process, variable in time and dependent on the changing ecological conditions $\langle\mathrm{L}$ e v i t t, 1956; 1972; G r z e s i u k et al., 1974〉.

With frost resistance of plants are connected both the mechanisms which enable the plant to avoid freezing of the tissues and those which protect the tissues from the consequences of freezing, especially from severe dehydration of the cells $\langle\mathrm{K}$ a c p e r s k a-P a la c z, 1970; 1978〉.

In breeding work for frost-resistance the most reliable results are obtained in field observation under natural conditions. Since severe winters selectioning the material are relatively rare in this country, it is necessary to conduct investigations on frost-hardiness of plants under laboratory conditions $\langle\mathrm{K}$ o c z o w$\mathrm{s} \mathrm{k} \mathrm{a}, 1969$; $\mathrm{D} \mathrm{o} \mathrm{n} \mathrm{i} \mathrm{c} \mathrm{k} \mathrm{i,} \mathrm{1975 \rangle .} \mathrm{Among} \mathrm{the} \mathrm{numerous} \mathrm{methods} \mathrm{of} \mathrm{frost-}$ -hardiness evaluation $\langle\mathrm{K} \mathrm{a} \mathrm{c} \mathrm{p} \mathrm{e} \mathrm{r} \mathrm{s} \mathrm{k} \mathrm{a-P} \mathrm{a} 1$ a c z and D l u g o k e c k a, 1971; $\mathrm{H}$ of $\mathrm{f} \mathrm{m}$ a $\mathrm{n}$ et al., 1975 $>$ especially noteworthy are the studies utilizing 
the detection of delayed luminescence of green plants $\langle\mathrm{B} \mathrm{r} \mathrm{z} \mathrm{ó} \mathrm{s} \mathrm{t} \mathrm{o} \mathrm{w} \mathrm{i} \mathrm{c} \mathrm{z} \mathrm{et}$ al., 1981 $\rangle$. The luminescence methods are of high precision, the measurement time is short and the plants examined may be further used for breeding.

The phenomenon of delayed luminescence $\langle\mathrm{S} \mathrm{t} \mathrm{r}$ e h l e r and A r n o ld, $1951>$ has been utilized for long years both in investigations of the process of photosynthesis itself and of phenomena connected with photosynthesis $<\mathrm{E} \mathrm{s}$ s e r, 1969; S h u valov and Litvi n, 1969; A r nold and Azzi, 1971; M u r k ow ski, 1974).

External stress factors disturbing the functioning of the photosynthetic apparatus cause changes in the intensity and character of delayed luminescence emission $\langle\mathrm{D}$ o s k o c h et al., 1976: L a v o r e 1, 1969; $\mathrm{K}$ i t 1 a e v and T a r u s ov, 1970; M urk ow ski, 1974; T a r u s o v and V e s e-

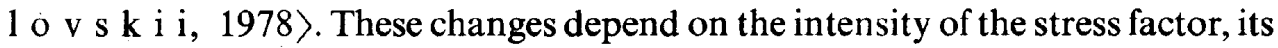
duration and the susceptibility of the plant. This allowed the application of delayed luminescence detection for developing methods of frost-resistance evaluation $\langle\mathrm{Dzh}$ a n m o v et al., 1978; T a r u s o v et al., 1976; T a r u s ov and Veselovski i, 1978>.

The present authors undertook development and testing in practice of the luminescence method for frost-hardiness evaluation in cereal plants, and part of the results concerning the hardiness of winter wheat is the subject of this paper.

\section{MATERIAL AND METHODS}

The material consisted of leaves of three winter wheat $\langle$ Triticum $\rangle$ varieties: 'Mironowska 808', 'Grana' and 'Maris Huntsman' from experimental plots in Szczecin Zdroje. The plants were uprooted and transferred to a refrigerator 〈fluorescence light of $25 \mathrm{~W} \cdot \mathrm{m}^{-2}$ intensity, temperature equal to the air temperature on the day of collection of the plants $>$ and the temperature was changed at a rate of $1^{\circ} \mathrm{C} \cdot \mathrm{h}^{-1}$ down to $5^{\circ} \mathrm{C}$. After $24 \mathrm{~h}$ segments of leaves $4 \mathrm{~cm}$ long were collected for investigation. They were placed in a measuring chamber on the surface of a thermobattery previously cooled to $0^{\circ} \mathrm{C}$. After $3 \mathrm{~min}$ of adaptation the temperature was depressed within the interval of $0^{\circ}$ to $-20^{\circ} \mathrm{C}$ at a rate $1^{\circ} \mathrm{C} \cdot \mathrm{min}^{-1}$. In the course of temperature fall the plants were irradiated at minute intervals for $2 \mathrm{~s}$ with light of $30 \mathrm{~W} \cdot \mathrm{m}^{-2}$ intensity. Two seconds after switching off the inducing light the intensity of delayed luminesce was recorded during two successive seconds. The measurement cycle was repeated at 1-min intervals. As index of frost-resistance the temperature $\left\langle t_{N}\right\rangle$ was assumed at which the intensity of delayed luminescence was highest.

Simultaneously frost-resistance was measured by the conductometric method $\langle\mathrm{K}$ a c per s k a-P a $\mathrm{lacz}$ and D $\mathrm{u} \mathrm{g} \mathrm{o} \mathrm{k} \mathrm{e} \mathrm{c} \mathrm{k} \mathrm{a,} \mathrm{1971 \rangle ,} \mathrm{modified} \mathrm{by} \mathrm{the}$ present authors. In the method used plants without roots were taken and the process of their "complete killing" was run during $16 \mathrm{~h}$ at $-30^{\circ} \mathrm{C}$ <instead of $\left.+100^{\circ} \mathrm{C}\right\rangle$. Temperature $\left\langle\mathrm{t}_{50}\right\rangle$ at which 50 per cent of the plant tissues is damaged served as index of hardiness. 
The material was collected in the middle of each month from November 15 , 981 to March 15, 1982.

All measurements of delayed luminescence $\langle\mathrm{DL}\rangle$ were carried out in four replications, and the conductometric measurements in ten replications. Errors in measurement graphically marked on the diagrams were calculated by the Student-Fisher method for the confidence level 0.95 .

\section{RESULTS}

A block diagram of the measuring system of delayed luminescence is shown in Figure 1, and the results of frost-resistance evaluation of the tested winter wheat cultivars 〈A - 'Maris Huntsman', B - 'Grana', C - 'Mironowska 808'〉

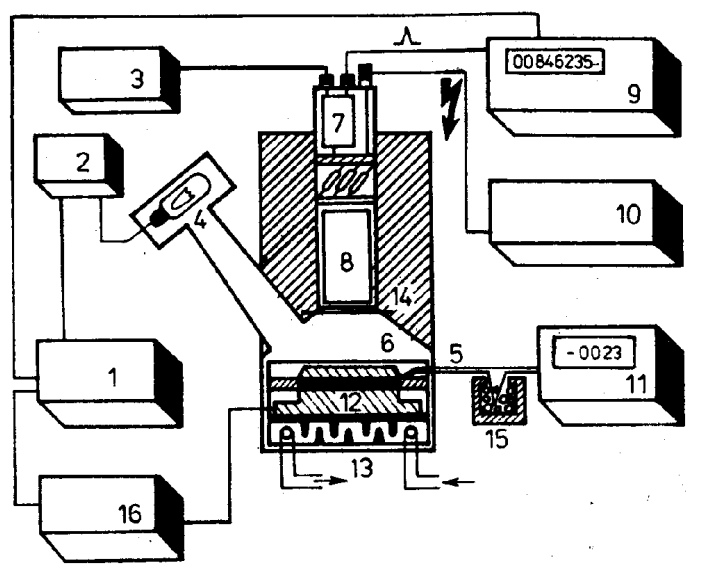

Fig. 1.. Block diagram of system for maesurements of delayed luminescence intensity of plants at different temperatures: 1 - programming system, 2 - autotransformer, 3 - stabilized power supply, 4 - projection lamp, 5 - thermocouple, 6 - lightproof camera, 7 - amplifier, 8 - photomultiplier, 9 - counter, 10 - high voltage power supply, 11 - voltmetre, 12 - thermoelectric battery, 13 - water cooler, 14 - diaphragm, 15 - vacuum flask with ice, 16 - low voltage power supply

obtained by the luminescence and conductometric methods are shown in Figure 2. As seen, the values $\left\langle t_{N}\right\rangle$ and $\left\langle t_{50}\right\rangle$ change, reaching minimum in February. This is probably due to the progressing natural adaptation (hardiness development $\rangle$ in the plants, connected with the occurrence of severe frost in this period $\langle$ Fig. 3 $\rangle$. In March $\left\langle t_{N}\right\rangle$ and $\left\langle t_{50}\right\rangle$ drastically increase and their values exceed even the autumn ones. This may be evidence of loss of hardiness by the plants, owing to the temperature rise in the end of February and in March, when the mean diurnal temperature reached as much as $+8^{\circ} \mathrm{C}\langle$ Fig. 3$\rangle$. 

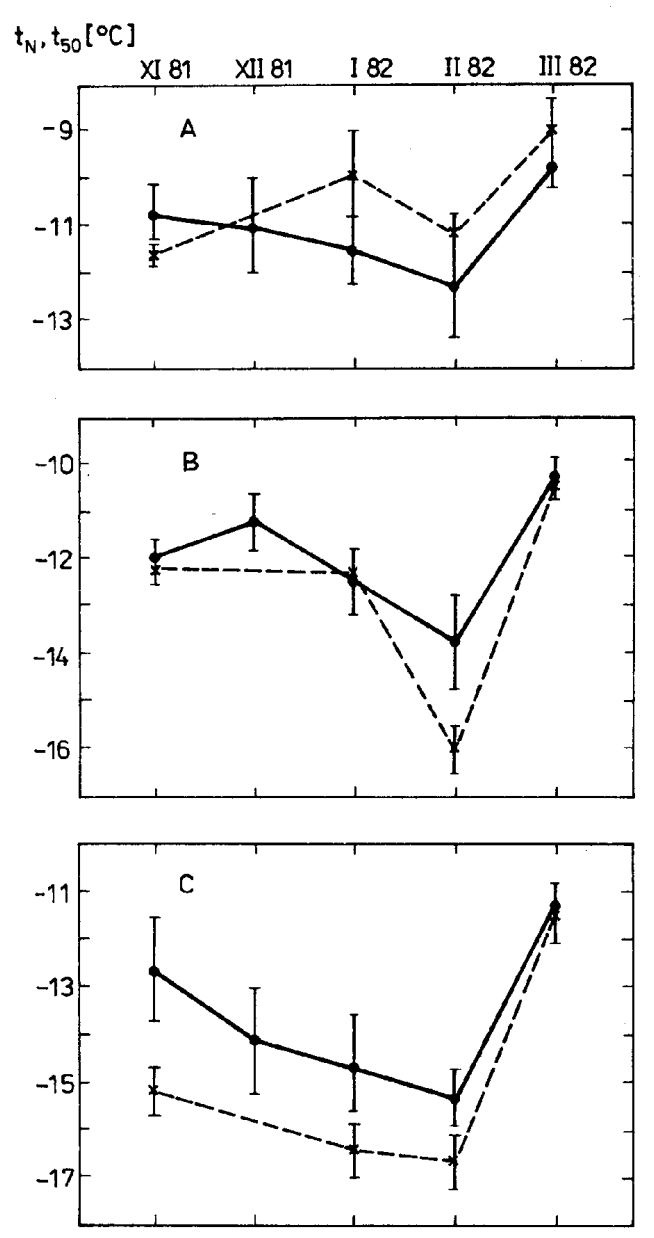

Fig. 2. Average $t_{N}\langle-\cdot\rangle$ and $t_{50}$ values $\langle-x-\rangle$ measured during autumn and winter season 1981/82 for wheat winter cultivars: A - 'Maris Huntsman', B - 'Grana', C - 'Mironowska 808'

The $\left\langle t_{N}\right\rangle$ and $\left\langle t_{50}\right\rangle$ temperatures were over the whole period of investigation higher for the cultivar 'Maris Huntsman' than for the cultivar 'Grana' and 'Mironowska 808'. This indicates, in agreement with literature data $\langle\mathrm{D}$ o 1$\mathrm{n} \mathrm{i} \mathrm{c} \mathrm{k} \mathrm{i,} \mathrm{1975>,} \mathrm{that} \mathrm{the} \mathrm{cv.} \mathrm{'Maris} \mathrm{Huntsman'} \mathrm{is} \mathrm{unresistant} \mathrm{to} \mathrm{low} \mathrm{temperature,}$ 'Grana' is medium-resistant and 'Mironowska 808 ' is the most resistant of the tested plants.

The results of evaluation of frost-resistance of three winter wheat varieties obtained by the described, measurement methods show good agreement of the $\left\langle t_{N}\right\rangle$ and $\left\langle t_{50}\right\rangle$ values for the particular cultivars in the whole autumn-winter period. 


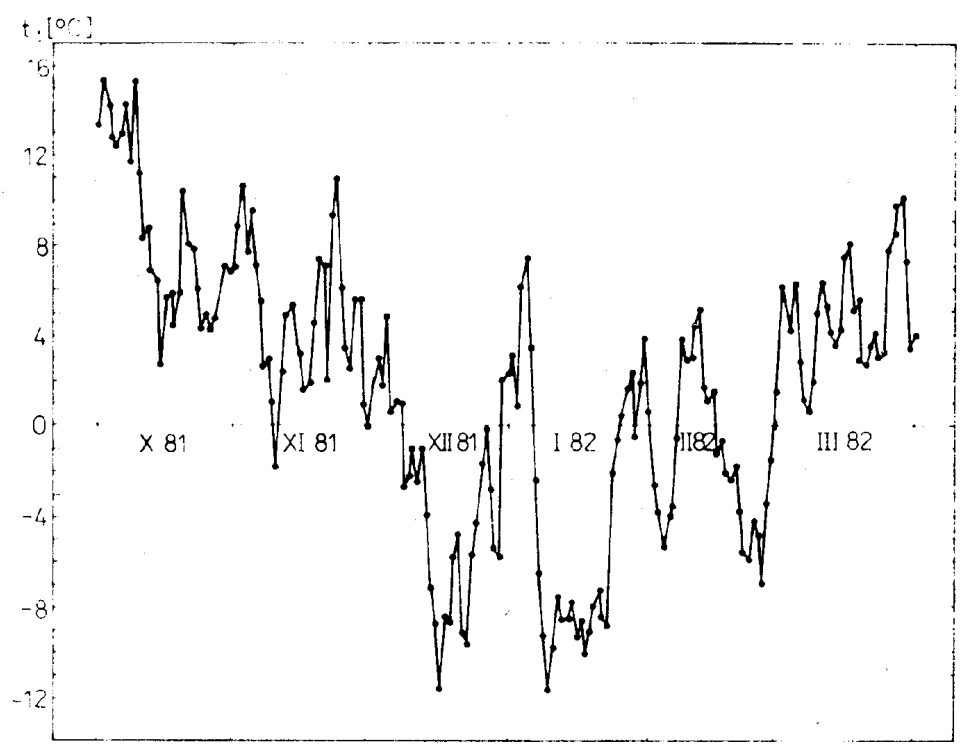

Fig. 3. Average diurnal temperatures $\left\langle t_{d}\right\rangle$ for autumn and winter season 1981/82

\section{CONCLUSIONS}

1. Measurement of delayed luminescence $\langle\mathrm{DL}\rangle$ demonstrated differences in hardiness of the tested wheat varieties. As expected, the temperature at which maximum DL was observed was lowest for the frost-resistant variety, 'Mironowska 808' and highest for the low-resistance variety 'Maris Huntsman'.

2. The investigations showed the usefulness of the luminescence method for evaluation of the frost-resistance of various winter wheat varieties and for observation of their resistance during adaptation to cold.

\section{REFERENCES}

A r n o ld W., A z z i J. R,, 1971. The mechanism of delayed light production by photosynthetic organisms and a new effect of electric fields on chloroplasts. Photochem. and Photobiol. 14: 233-240.

B rzóst ow i c z A., Grabik ow sk i E., M urk owski A., 1981. Luminescencyjne metody oceny mrozoodporności zbóż ozimych. Post. Nauk Rol. 4: 37-53.

D o l n i cki A., 1975. Problemy fizjologicznych i biochemicznych podstaw zimotrwalości pszenicy i jęczmienia. Biuletyn IHAR 1-2: 141-149.

D o s k o ch J. F., T a r u s o v B. N., A g a ve rde v A. S., 1976. Biofizicheskie metody diagnostiki ustoichivosti rastenii $\mathrm{k}$ neblagopriyatnym temperaturnym usłoviyam. Metody ocenki ustoichivosti rastenii $\mathrm{k}$ neblagopriyatnym usloviyam sredy. Leningrad, Izd. Kolos: 205-221.

D zhanumov D. A., B o charov E. A., K 1 i mov S. W., 1978. Biofizicheski metod opredeleniya morozoustoichivosti ozimykh pshenits na rannykh etapakh prorashchivaniya. Selskokhoz. biol. 13: 302-306. 
E s s e r A., 1969. Lumineszenz von Grunalgen - Dissertation. Uniw. Frankfurt/Main.

Grzes i u k S., L o gi n A., R e jow s k i A., S ó j k a E., 1974. Mrozoodporność pszenic i jej związek z jakością białek w węzlach krzewienia. Hod. Rośl. Aklim. 18: 1-10.

H o f f $m$ a n W., M u d r a A., P l a r r e W., 1975. Ogólna hodowla roślin. PWRiL, Warszawa.

$\mathrm{K}$ a c p e r s k a-P a 1 a c z A., 1970. Mrozoodporność roślin - współczesne poglądy na istotę tego zjawiska. Post. Nauk Rol. 1/2: 107-120.

K a c p e r s k a-P a 1 a c z A., D $\nmid$ u g o k ę c k a E., 1971. Metodyka przeprowadzania oceny odporności roślin na zamarzanie. Wiad. Bot. 15: 79-90.

K a c p e r s k a-P a 1 a c z A., 1978. Mechanisms of cold acclimation in herbaceous plants. [In:] P. H. Li and A. Sakai 〈ed.〉 Plant Cold Hardiness and Freezing Stress. Academic Press, New York: 139-152.

K i t l a e v B. N., T a r u s o v B. N., 1970. Nizkotemperaturnye vspyshki fotosinteticzeskoi luminescencii rastienii. DAN SSSR 195: 725-727.

K o c z o w s k a I., 1969. Porównanie kilku metod badania mrozoodporności jęczmienia ozimego w warunkach laboratoryjnych. Zesz. Nauk. WSR Olsztyn 25: 967-984.

$\mathrm{L}$ a v o r e $1 \mathrm{~J}$., 1969. On a relation between fluorescence and luminescence in photosynthetic systems. Progress in Photosynth. Research, Tubingen 2: 883-898.

L:e v it $t$ J., 1956. The hardiness of plants. Academic Press, New York.

I e y i t t J., 1972. Responses of plants to environmental stresses. Academic Press, New York.

M u r k ow s k i A., 1974. Fotosyntetyczna luminescencja - wskaźnikiem stanu fizjologicznego rośliny i jej odporności na ekstremalne czynniki zewnętrzne. Post. Nauk Rol. 4: 3-16.

S \& r e h 1 e r B. L., A r n o 1 d W. A., 1951. Light production by green plants. J. Gen. Physiol. 34: $809-820$.

1.h u w a 1 o v W. A., L i t v i n F. F., 1969. O mechanizme dlitelnovo poslesvecheniya listev rastenii i zapasanii energii w reakcennykh centrach fotosinteza. Mol. Biol. 3: 59-73.

T a r u s o v B. N., K i t l a e v B. N., D o s k o c h J. E., 1976. Biofizicheskie metody diagnostiki ustoichivosti rastenii i perspektiwy ikh primeneniya w selekcii. Metody ocenki ustoichivosti rastenii k neblagopriyatnym usloviyam sredy. Leningrad, Izd. Kolos: 191-204.

T a r u s ov B. N., Ves elovsk i W. A., 1978. Sverkhslabye swechenie rastenii i ich prikladnye znachenie. Moskva, Izd. MU.

Wykorzystanie testu luminescencyjnego do oceny zmian mrozoodpornošci pszenicy ozimej

\section{Streszczen i e}

Zbadano wpływ jesienno-zimowego hartowania na mrozoodporność trzech odmian pszenicy' ozimej 〈'Mironowska 808', 'Grana', i ‘Maris Huntsman'〉. Ocenę mrozoodporności przeprowadzano co miesiąc testem luminescencyjnym i metodą konduktometryczną. Jako wskaźnik mrozoodpotności w metodzie luminescencyjnej przyjęto temperaturę $\left\langle t_{N}\right\rangle$, w której występuje maksimum natężenia opóźnionej luminescencji. Natomiast metodą konduktometryczną wyznaczano temperaturę $\left\langle\mathrm{t}_{50}\right\rangle$, która powoduje uszkodzenia $50 \%$ tkanek.

W trakcie hartowania róślin zarejestrowano wyraźne różnice w mrozoodporności badanych odmian oraz obniżanie się $\left\langle t_{N}\right\rangle \mathrm{i}\left\langle t_{50}\right\rangle$. Stwierdzono również dużą zgodność między wartościami $\left\langle t_{N}\right\rangle \mathrm{i}\left\langle\mathrm{t}_{50}\right\rangle$ badanych odmian w ciagu calego hartowania. 